Saudi Journal of Medical and Pharmaceutical Sciences

Abbreviated Key Title: Saudi J Med Pharm Sci ISSN 2413-4929 (Print) |ISSN 2413-4910 (Online) Scholars Middle East Publishers, Dubai, United Arab Emirates Journal homepage: https://saudijournals.com/sjmps

\title{
Evaluation of Sexual Behaviour in Momordica Charantia Treated Male Wistar Rats
}

\author{
Chibuike Obiandu*, Prince C. Achinike \\ Department of Human Physiology, Faculty of Basic Medical Sciences, College of Health Sciences, University of Port Harcourt, Nigeria
}

\begin{tabular}{ll}
\hline DOI: $10.36348 /$ sjmps.2020.v06i02.007 & | Received: 03.02.2020 | Accepted: 15.02 .2020 | Published: 20.02 .2020 \\
*Corresponding author: Chibuike Obiandu &
\end{tabular}

Abstract

The effect of leaf extract of Momordica charantia on sexual behaviour of male wistar rats was evaluated in this study. The animals were randomly divided into three (3) groups of six (6) rats each. Group one (1) serving as control received distilled water while, groups two (2) and three (3) received $200 \mathrm{mg} / \mathrm{kg}$ and $400 \mathrm{mg} / \mathrm{kg}$ of the hydromethanol (20\%:80\%) extract respectively. Parameters assessed included the mount frequency (MF), mount latency (ML), intromission frequency (IF), intromission latency(IL), ejaculation frequency(EF) and ejaculation latency(EL). Results showed that the parameters were not significantly altered after 30 days treatment with $200 \mathrm{mg} / \mathrm{kg}$ and $400 \mathrm{mg} / \mathrm{kg}$ extract. It was concluded that $M$. charantia may not affect sexual activity in male wistar rats within the administered doses.

Keywords: Momordica charantia, wistar rats, hydromethanol.

Copyright @ 2020: This is an open-access article distributed under the terms of the Creative Commons Attribution license which permits unrestricted use, distribution, and reproduction in any medium for non-commercial use (NonCommercial, or CC-BY-NC) provided the original author and source are credited.

\section{INTRODUCTION}

$$
\begin{aligned}
& \text { Some scientific studies on Momordica } \\
& \text { charantia (M. charantia) focused on investigating } \\
& \text { effects of the plant extract on reproductive parameters } \\
& \text { of male wistar rats. A good number of these studies } \\
& \text { referred to changes in the pituitary-testicular axis and } \\
& \text { sperm production in male rats. The serum Luteinizing } \\
& \text { Hormone (LH), Follicle Stimulating Hormone (FSH) } \\
& \text { and Testosterone (T) effects as well as the sperm } \\
& \text { quality were analysed and documented [1][2]. } \\
& \text { However, the serum T has often been related to male } \\
& \text { sexual behavior (MSB). Sexual behavior refers to a } \\
& \text { process by which human beings and other animals } \\
& \text { demonstrate and/or express their sexuality. Male sexual } \\
& \text { behavior (MSB) presents two different phases- an initial } \\
& \text { phase, with variable behavioural sequence involving } \\
& \text { attracting and courting the female, followed by highly } \\
& \text { stereotyped copulatory sequence. Disorders affecting } \\
& \text { the sexual behavior of the male may present in various } \\
& \text { forms such as erectile dysfunction, premature } \\
& \text { ejaculation and orgasmic disorders amongst others [3]. } \\
& \text { Consequently, various treatment options including } \\
& \text { medicinal plants are been studied to determine their } \\
& \text { effects on MSB. The } M \text {. charantia is a popular plant } \\
& \text { used in folklore in the treatment of Diabetes and other } \\
& \text { conditions but the inherent effects of its use on MSB } \\
& \text { has not been adequately documented. The objective of } \\
& \text { this study is to investigate the aphrodisiac potential of } \\
& \text { the hydromethanolic leaf extract of } M \text {. charantia. }
\end{aligned}
$$

\section{Materials ANd Methods Animal models}

Eighteen randomly selected adult male rats bred in the animal house of the Faculty of Basic Medical Sciences, University of Port Harcourt were used for this study. They were placed in neat cages and acclimatized in two weeks. They were nurtured under standard conditions and had free access to water and feeds. The handling procedures conformed with standard institutional guidelines established by the American Physiological Society [4].

\section{Preparation of plant extract}

M. charantia leaves were procured from Choba community in Obio Akpor Local Government Area of Rivers State, Nigeria. They were washed, dried and blended to fine powder. Hydromethanol (20\%: $80 \%$ ) was used as solvent in the extraction using soxhlet apparatus at $60^{\circ \mathrm{C}}-70^{\mathrm{oC}}$. The solution was then filtered and the filtrate was concentrated to a semi solid form under reduced pressures at $60^{\circ} \mathrm{c}$ with the aid of a rotary evaporator. The extract yield was weighed and stored in the refrigerator at $4^{\circ} \mathrm{C}$. Measured quantity of the extracts were diluted to obtain $400 \mathrm{mg} / \mathrm{ml}$ of the extract for animal oral treatments. 


\section{Experimental design}

The rats were randomly assigned into 3 groups of 6 rats each. Group 1 served as control and was given distilled water. Group 2 and group 3 were given $200 \mathrm{mg} / \mathrm{kg}$ bw and $400 \mathrm{mg} / \mathrm{kg}$ bw of the hydromethanol leaf extract respectively. They weighed between 155$165 \mathrm{~g}$. Extracts were administered orally as single daily dose for 30 days.

\section{Sexual behavior test}

The methods adopted for this experiment has been described in previous studies and are well documented [5-9]. In the present study, six (6) male rats from each group were monitored for sexual behavior for a period of 30 minutes. Sexual behavior experiments were carried out during the first 4 hours of the 12 hours dark cycle and 3 hours after extract administration. The test male rat was introduced into the observation cage and allowed 10 minutes for adaptation before the stimulus female was introduced. The chemically prepared receptive female and test male rats were observed from a corner for precopulatory and copulatory behaviours.

Tests for sexual behavior was done by assessing: Mount latency (ML); Intromission latency (IL); Ejaculation latency (EL); Mount frequency (MF); Intromission frequency (IF) and Ejaculation frequency (EF).

\section{Statistical AnAlysis}

Analysis was carried out on SPSS version 21 using analysis of variance (ANOVA). Results are presented as mean \pm standard error of mean. The level of significance was considered at $\mathrm{P}<0.05$.

\section{RESULT} 2 and 3 .

The result of this study is presented in tables1,

Table 1: Effect of $M$. charantia extract on Mount behaviours

\begin{tabular}{|l|l|l|}
\hline \multirow{2}{*}{ Groups } & \multicolumn{2}{|c|}{ Mount behaviour } \\
\cline { 2 - 3 } & Latency (Sec) & Frequency (n) \\
\hline Control & $54.16 \pm 5.79$ & $13.00 \pm 0.73$ \\
\hline $200 \mathrm{mg} / \mathrm{kg}$ & $61.16 \pm 2.56$ & $12.00 \pm 0.57$ \\
\hline $400 \mathrm{mg} / \mathrm{kg}$ & $60.00 \pm 3.96$ & $11.66 \pm 0.66$ \\
\hline
\end{tabular}

Values expressed as Mean \pm SEM. $\mathrm{n}=6$.

Table-2: Effect of $M$. charantia extract on Intromission behaviours

\begin{tabular}{|l|l|l|}
\hline \multirow{2}{*}{ Groups } & \multicolumn{2}{|c|}{ Intromission behaviour } \\
\cline { 2 - 3 } & Latency (Sec) & Frequency (n) \\
\hline Control & $58.33 \pm 4.24$ & $4.25 \pm 0.44$ \\
\hline $200 \mathrm{mg} / \mathrm{kg}$ & $63.50 \pm 4.19$ & $3.33 \pm 0.33$ \\
\hline $400 \mathrm{mg} / \mathrm{kg}$ & $63.00 \pm 2.39$ & $3.33 \pm 0.33$ \\
\hline
\end{tabular}

Values expressed as Mean \pm SEM. $\mathrm{n}=6$.
Table-3: Effect of $M$. charantia extract on Ejaculation behaviours

\begin{tabular}{|l|l|l|}
\hline \multirow{2}{*}{ Groups } & \multicolumn{2}{|c|}{ Ejaculation behaviour } \\
\cline { 2 - 3 } & Latency (Sec) & Frequency (n) \\
\hline Control & $161.16 \pm 8.24$ & $0.83 \pm 0.16$ \\
\hline $200 \mathrm{mg} / \mathrm{kg}$ & $180.16 \pm 8.58$ & $0.66 \pm 0.21$ \\
\hline $400 \mathrm{mg} / \mathrm{kg}$ & $183.66 \pm 9.73$ & $0.50 \pm 0.22$ \\
\hline
\end{tabular}

Values expressed as Mean \pm SEM. $n=6$

\section{DISCUSSION}

The MF and IF are important measures of libido and potency [10], while significant decrease or increase in ML and IL are indicators of sustained increase or decrease respectively, in sexual activity and aphrodisiac property of a plant extract [11].

In this study there was no significant $(\mathrm{P}<0.05)$ change in ML and MF when test groups were compared to control in both doses $(200 \mathrm{mg} / \mathrm{kg}$ and $400 \mathrm{mg} / \mathrm{kg}$ ) of extract. Similarly, the IL and IF as well as, EL and EF were not significantly $(\mathrm{P}<0.05)$ affected after 30 days of extract administration.

A significant increase in $\mathrm{MF}$ and $\mathrm{IF}$ and a decrease in the ML and IL indicates sexual arousability, motivation and sexual vigour $[12,13]$. These are characteristic effects of medicinal plants with aphrodisiac potentials.

The observed unaltered EL suggest that the extract could not cause a delay in ejaculation thereby did not prolong coital period and did not improve sexual activity. The inability to prolong duration of coitus observed in this study suggests that the extract may not be able to reduce the incidence of early or premature ejaculation.

Although existing reports shows that $M$. charantia leaf extract caused significant reductions in serum $\mathrm{T}[1,14]$, this did not lead to a significant decrease in male sexual behaviours. According to a report, a significant change in serum $\mathrm{T}$ may be able to influence male sexual behavior [15]. However, findings shows that no parameter used in assessing male sexual behavior was significantly altered in our study.

\section{CONCLUSION}

M.charantia leaf extract neither significantly increased nor decreased Male sexual behavior parameters after 30 days of administration at $200 \mathrm{mg} / \mathrm{kg}$ and $400 \mathrm{mg} / \mathrm{kg}$ doses.

\section{REFERENCES}

1. Obiandu, C., Nnadozie, A.G., Azubuike, B.S., Achinike, P.N., Okari, K., \& Obiandu, A.C. (2020). Reduction in Some Reproductive Indices of Momordica Charantia Treated Male Wistar Rats. 
Scholars Journal of Applied Medical Sciences, 8(1): 268-273

2. Sheeja, E.J., Ajeet, P., Bigoniya, P., \& Singh, S. (2012). Antifertility activity of Momordica charantia descourt pulp and Seed hydroalcoholic extract Journal of Applied Pharmacy, 03(04): 682696.

3. Yakubu, M.T. (2006). Aphrodisiac potentials and toxicological evaluation of aqueous extract of Fadogia agrestis Schweininf ex. Hiern) stem in male rats. Ph.D. Thesis. University of Ilorin, Ilorin Nigeria.

4. American Physiological Society. (2002). Guiding principles for research involving animals and human beings. American journal of physiology, regulatory, integrative and comparative physiology, 283: $281-283$

5. Yakubu, M.T., Akanji, M.A., \& Oladiji, A.T. (2007). Male sexual dysfunction and methods used in assessing medicinal plants with aphrodisiac potentials. Pharmacognosy Reviews, 1(1) 49-56.

6. Dewsbury, D.A., \& Davis, H.N. (Jr). (1970). Effect of Reserpine on the copulatory behavior of male rats. Physiology and Behaviour, 5: 1331 - 1333.

7. Madlafousek, J., Hliňak, Z., \& Pař́zek, J. (1971). Sexual Behaviour of male rats sterilized by cadmium. Journal of reproduction and fertility.26:189-196

8. Adienbo, O.M., Nwafor, A., \& Ronami, S.O. (2013). Effect of Hydromethanolic extract of xylopia aethopica on sexual behavior in male wistar rats. International journal of Advanced Biological Research, 1(9): 1078 - 1085.
9. Obiandu, C., Adienbo, O., Chuemere, A.N. (2018).The Effects of Hydromethanolic Extracts of Uncoated and Coated Seeds of Garcinia Kola on the Sexual Behaviour of Male Wistar Rats. International Journal of Innovative Research \& Development, 7(11):333-338

10. Meisel, R.L., \& Sachs, B.D. (1994). The physiology of male sexual behavior. IN: Knobil E and Neil JD (Eds). The physiology of reproduction. $2^{\text {nd }}$ Edn, Raven press, New York. 2:3-105.

11. Yakubu, M.T. (2006). Aphrodisiac potentials and toxicological evaluation of aqueous extract of Fadogia agrestis Schweininf ex. Hiern) stem in male rats. Ph.D. Thesis. University of Ilorin, Ilorin Nigeria.

12. Ratnasooriya, W.D., \& Dharmasiri, M.G. (2000). Effects of Terminalia catappa seeds on sexual behavior and fertility of male rats. Asian Journal of Andrology, 2:213-219.

13. Yakubu MT., AkanJi MA and Oladiji AT. (2005). Aphrodisiac potentials of aqueous extract of fadogia agrestis schweinf. ex hiern stem in male albino rats. Asian journal of Andrology, 7(4):399404.

14. Yama, O.E., Duru, F.I., Oremosu, A.A., Noronha, C.C., \& Okanlawon, A. (2011). Suppressive effects of Momordica charantia on pituitary-testicular axis and sperm production in male Sprague-Dawley rats International Journal of Medicine and Medical Sciences, 3(12) : 353-359.

15. Yakubu, MT., Akanji, M.A., \& Oladiji, AT. (2007). Male sexual dysfunction and methods used in assessing medicinal plants with aphrodisiac potentials. Pharmacognosy Reviews, 1(1) 49-56. 